\title{
ANALISIS TEGANGAN BIDANG (PLANE STRESS) DINDING GESER (SHEAR WALL) GEDUNG BERTINGKAT
}

\author{
Sondra Raharja \\ Mahasiswa Magister Teknik Sipil Universitas Riau \\ Jalan Subrantas Km 12,5 Pekanbaru, 28293 \\ E-mail : sondra.raharja@ student.unri.ac.id \\ Reni Suryanita \\ Magister Teknik Sipil Universitas Riau \\ Jalan Subrantas Km 12,5 Pekanbaru, 28293 \\ E-mail : reni.suryanita@ lecturer.unri.ac.id \\ Zulfikar Djauhari \\ Magister Teknik Sipil Universitas Riau \\ Jalan HR. Soebrantas Panam Pekanbaru \\ E-mail : zulfikar.djauhari@lecturer.unri.ac.id
}

\begin{abstract}
Abstrak
Salah satu upaya untuk memperkuat struktur bangunan gedung bertingkat tinggi adalah dengan membuat shear wall yang terhubung dan terintegrasi dengan struktur portal gedung tersebut. Shear wall merupakan salah satu komponen struktur yang berfungsi untuk menahan gaya geser akibat timbulnya gaya lateral gempa. Gaya lateral gempa yang bekerja, menyebabkan timbulnya tegangan-tegangan pada bidang shear wall. Tegangan-tegangan bidang shear wall ini berupa tegangan normal arah $\mathrm{x}\left(\sigma_{\mathrm{xx}}\right)$, tegangan normal arah y $\left(\sigma_{\mathrm{yy}}\right)$ dan tegangan geser arah $\mathrm{xy}\left(\tau_{\mathrm{xy}}\right)$. Analisis tegangan bidang ini disebut juga Analisis Plane Stress, yaitu analisa tegangan bidang dengan perbandingan antara tebal dan lebar atau antara tebal dan tinggi adalah kecil. Jika tebal dalam arah sumbu z, maka z sangat kecil. Dalam riset ini, selain tegangan bidang shear wall yang dihasilkan dari analisis plane stress, juga diperoleh deformasi sebagai hasil dari terjadinya perpindahan akibat pengaruh gaya luar pada setiap elemen bidang. Joint displacement yang paling besar terjadi pada titik paling atas pada shear wall, yaitu sebesar 0.26 m pada titik 20 dan 21. Sedangkan pada titik paling bawah atau pada dasar tidak terjadi perpindahan, karena pada dasar shear wall, joint dikekang dengan perletakan sendi. Kemudian dari hasil perpindahan tersebut akan dihasilkan gaya dan regangan pada setiap elemen bidang shear wall.Tegangan maksimum terjadi pada elemen 1, yaitu elemen yang paling bawah dari shear wall. Besar tegangan pada elemen ini adalah sebesar $\sigma_{\mathrm{xx}}=4039,579 \mathrm{kN} / \mathrm{m}^{2}, \sigma_{\mathrm{yy}}=20197,579 \mathrm{kN} / \mathrm{m}^{2}$ dan $\tau_{\mathrm{xy}}=14208,841$ $\mathrm{kN} / \mathrm{m}^{2}$. Hasil tegangan bidang tersebut selanjutnya digunakan untuk perencanaan konstruksi beton bertulang shear wall.
\end{abstract}

Kata Kunci : Dinding Geser, Lateral, Perpindahan, Tegangan Bidang 


\begin{abstract}
One of the efforts to strengthen the structure of high-rise buildings is to create a shear wall that is connected and integrated with the building's portal structure. Shear wall is one component of the structure that serves to resist the shear force due to the emergence of lateral forces of the earthquake. The lateral force of an earthquake that acts on the shear wall, causing stress in the plane of the shear wall. The stresses of the field of the shear wall are the normal stresses of direction $x\left(\sigma_{x x}\right)$, the normal direction stresses of $y\left(\sigma_{y y}\right)$ and the $x y\left(\tau_{x y}\right)$ direction shear stress. This field stress analysis is also mentioned Plane Stress Analysis. In this study, in addition to the shear field stresses generated from the plane stress analysis, also obtained deformation as a result of the displacement due to the influence of outer forces on each element of the field. The largest displacement point occurs at the uppermost point of the shear wall, which is $0.26 \mathrm{~m}$ at point 20 and 21. While at the bottom or at the bottom there is zero displacement, because at the base of the shear wall, joint restrained by joint placement. Then from the results of the displacement will be generated force and strain on every element of the shear wall. The maximum stresses occurs in element 1, the bottom element of the shear wall. The magnitude of this element stresses is $\sigma_{x x}=4039,579$ $\mathrm{kN} / \mathrm{m}^{2}, \sigma_{y y}=20197,579 \mathrm{kN} / \mathrm{m}^{2}$ and $\tau_{x y}=14208,841 \mathrm{kN} / \mathrm{m}^{2}$. The result of the field stress is further used for the construction planning of shear wall reinforced concrete.
\end{abstract}

Keywords : Shear Wall, Lateral, Displacement, Plane Streess

\section{A. PENDAHULUAN}

Salah satu upaya untuk memperkuat struktur banguan gedung bertingkat tinggi adalah dengan membuat dinding geser yang terhubung dan terintegrasi dengan struktur portal gedung tersebut. Dinding geser merupakan salah satu komponen struktur yang berfungsi untuk menahan gaya geser akibat timbulnya gaya lateral gempa.

Dinding geser merupakan dinding yang dirancang untuk menahan gaya lateral seperti gempa bumi. Dinding geser yang efektif adalah yang bersifat kaku dan kuat. Dalam struktur bertingkat, dinding geser sangat penting, karena selain untuk mencegah kegagalan dinding eksterior, dinding geser juga mendukung beberapa lantai gedung dan memastikan bahwa struktur tidak runtuh akibat gerakan lateral.

Dalam prakteknya dinding geser selalu dihubungkan dengan sistem rangka pemikul momen. Dinding struktural yang umum digunakan pada gedung tinggi adalah dinding geser kantilever dan dinding geser berangkai. Berdasarkan SNI 03-1726-2012 (BSN, 2012), dinding geser beton bertulang kantilever adalah suatu subsistem struktur gedung yang fungsi utamanya adalah untuk memikul beban geser akibat pengaruh gempa rencana. Kerusakan pada struktur dinding ini hanya boleh terjadi akibat momen lentur (bukan akibat gaya geser), melalui pembentukan sendi plastis di dasar dinding.

Gaya lateral gempa yang bekerja pada dinding geser, menyebabkan timbulnya tegangan-tegangan pada bidang dinding geser. Tegangantegangan bidang dinding geser ini berupa tegangan normal arah $\mathrm{x}$, tegangan normal arah y dan tegangan geser arah xy. Analisis tegangan bidang ini disebut juga Analisis Plane Stress. 
Dalam penelitian ini dilakukan kajian dinding geser pada bangunan Gedung Kantor Dinas Provinsi Riau Sembilan Lantai. Penelitian ini mengacu pada zonasi gempa Indonesia yang disajikan pada gambar 1 .

Analisis Plane Stress dalam penelitian ini merupakan analisis bertujuan yang untuk mengetahui tegangan-tegangan yang terjadi pada bidang dinding geser. Dalam melakukan analisis ini diperlukan data parameter yang digunakan untuk menganalisis antara lain mutu beton, modulus elastisitas bahan, poisson ratio bahan, tebal dan geometri dinding geser.

Analisis plane stress pada dinding geser ini dilakukan dengan perhitungan Metode Kekakuan Langsung (Direct Stifness) atau yang lebih dikenal dengan Metode Elemen Hingga (Finite Element
Method). Perhitungan secara manual ini akan diuji dengan program yang sudah dibuat dengan Matlab dan diuji juga dengan Software berbasis elemen hingga. Sehingga akan diperoleh hasil yang valid dari analisa tegangan bidang untuk dinding geser (shear wall).

Dalam penelitian ini, selain tegangan-tegangan bidang dinding geser yang dihasilkan dari analisis plane stress, juga akan diperoleh sebelumnya deformasi atau perubahan bentuk sebagai hasil dari terjadinya perpindahan (displacement) akibat pengaruh gaya luar. Kemudian dari hasil perpindahan (displacement) tersebut akan dihasilkan gaya-gaya dan regangan-regangan yang terjadi pada setiap elemen bidang dinding geser.

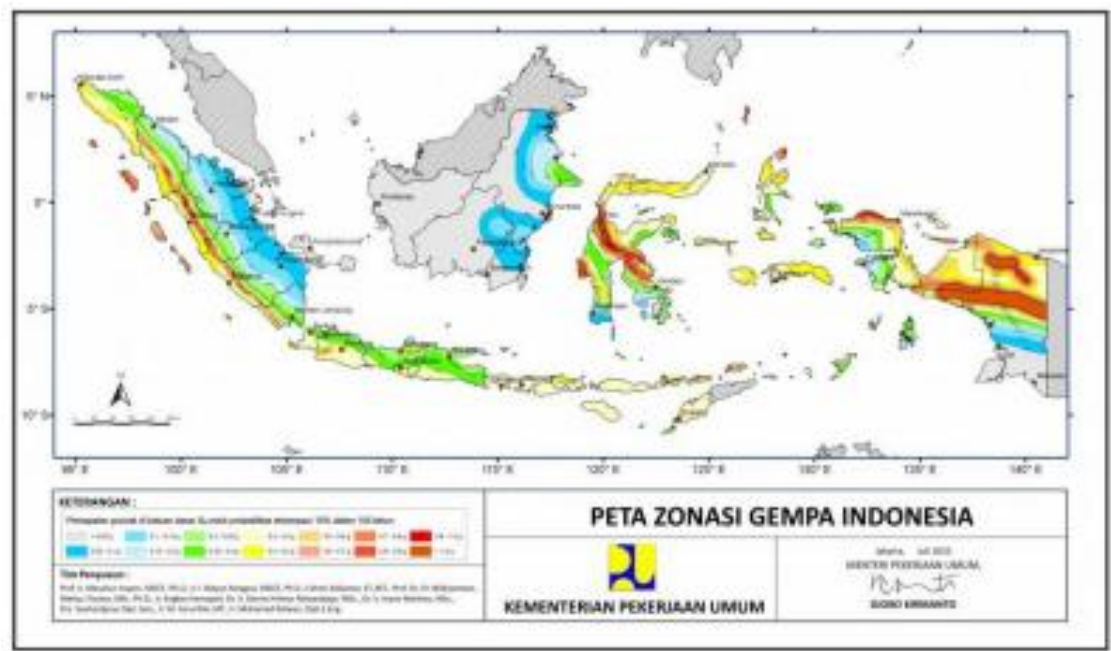

Gambar 1. Peta Zonasi Gempa

(Sumber : SNI 1726-2012)

\section{B. TINJAUAN PUSTAKA}

\section{Gempa Bumi}

Menurut Schodek (1999) gempa bumi terjadi akibat fenomena getaran dengan kejutan pada kerak bumi. Gempa ini menjalar dalam bentuk gelombang. Gelombang ini mempunyai suatu energi yang dapat menyebabkan permukaan bumi dan bangunan diatasnya menjadi bergetar. Getaran ini nantinya akan menimbulkan gaya-gaya pada struktur bangunan karena struktur cenderung mempunyai gaya untuk mempertahankan dirinya dari gerakan.

Menurut Chen, W.F dan Lui (2006), gempa bumi merupakan getaran yang terjadi pada permukaan tanah yang dapat disebabkan oleh aktivitas tektonik, vulkanisme, longsoran 
termasuk batu, bahan peledak. Dari semua penyebab tersebut $\mathrm{di}$ atas, goncangan yang disebabkan oleh peristiwa tektonik merupakan penyebab utama kerusakan struktur dan perhatian utama dalam kajian tentang bahaya gempa.

\section{Dinding Geser (Shear Wall)}

Sebagai subsistem struktur gedung, dinding geser fungsi utamanya adalah untuk memikul beban geser dari gaya lateral gempa. Dinding geser selalu dihubungkan dengan sistem rangka pemikul momen pada gedung.

Kerja sama antara sistem rangka penahan momen dan dinding geser merupakan suatu keadaan khusus, dimana dua struktur yang berbeda sifatnya tersebut digabungkan. Dari gabungan keduanya diperoleh suatu struktur yang lebih kuat dan ekonomis. Kerja sama ini dapat dibedakan menjadi beberapa macam :

a. Sistem rangka gedung, yaitu struktur yang pada dasarnya memiliki rangka ruang pemikul beban gravitasi secara lengkap. Pada sistem ini, beban lateral dipikul dinding geser atau rangka pengaku.

b. Sistem ganda, yang merupakan gabungan dari sistem pemikul beban lateral berupa dinding geser atau rangka pengaku dengan sistem rangka pemikul momen.

c. Sistem interaksi dinding geser dengan rangka. Sistem ini merupakan gabungan dari sistem dinding beton bertulang biasa dan sistem rangka pemikul momen biasa.

Secara umum sistem struktur dalam suatu konstruksi terdiri dari sistem struktur penahan beban gravitasi, dan sistem struktur penahan beban lateral.

\section{Analisis Plane Stress}

Pelat datar tipis merupakan elemen tegangan bidang. Gaya luar yang bekerja adalah traksi tegangan geser dan tegangan dalam bidang. Elemen tegangan bidang merupakan elemen yang paling sederhana dalam sistem struktur kontinum, seperti pada struktur dinding geser (shear wall), konstruksi plat dengan pengaku, gorong-gorong, pelat cangkang (membrane) dan shell.

Plane stress mengasumsikan bahwa tebal struktur material (z-axis atau sumbu z) sangat kecil jika dibandingkan dengan $\mathrm{x}$-axis atau sumbu $\mathrm{x}$ ataupun $\mathrm{y}$-axis atau sumbu $\mathrm{y}$. Tegangan yang terjadi dalam plane stress adalah tegangan normal $\mathrm{x}$-axis $(\sigma)$, tegangan normal y-axis $(\sigma)$, tegangan geser bidang $\mathrm{xy}(\tau)$.

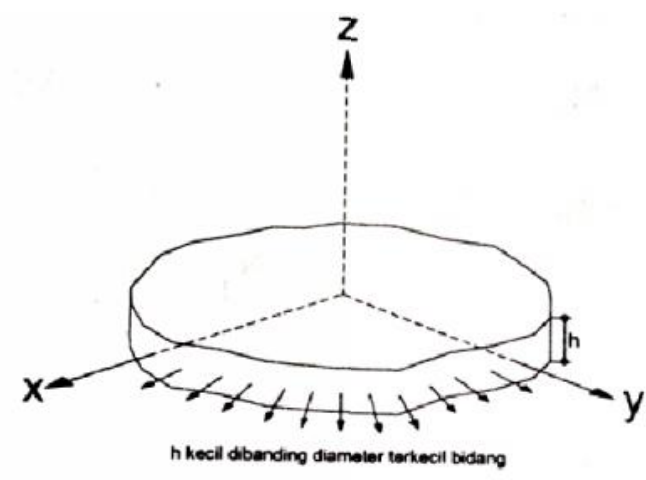

Gambar 2. Tegangan Bidang (Sumber : Amrinsyah N., 2010)

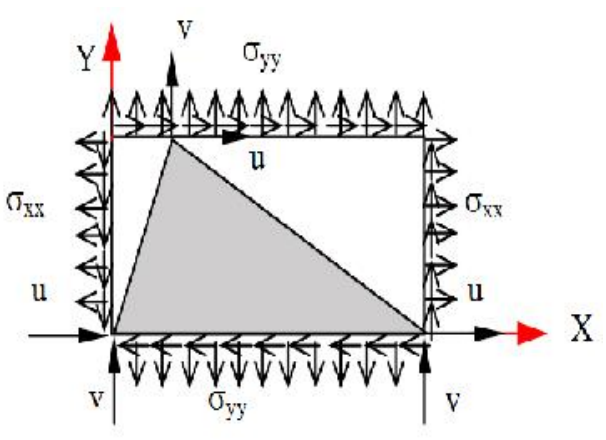

Gambar 3. Tegangan pada Elemen Segitiga 
Gambar 3 memperlihatkan struktur dasar dari tegangan bidang. Tegangan bidang didefinisikan :

$$
\begin{aligned}
& \sigma_{\mathrm{xz}}=\sigma_{\mathrm{yz}}=\sigma_{\mathrm{zz}}=0 \\
& \varepsilon_{\mathrm{xz}}=\varepsilon_{\mathrm{yz}}=0, \quad \varepsilon_{\mathrm{zz}} \neq 0 \\
& \sigma_{\mathrm{zx}}=\sigma_{\mathrm{zy}}=0 \mathrm{~V}_{\mathrm{b}}
\end{aligned}
$$

$$
\left\{\begin{array}{c}
\sigma_{\mathrm{xx}} \\
\sigma_{\mathrm{yy}} \\
\tau_{\mathrm{xy}}
\end{array}\right\}=\frac{\mathrm{E}}{1-\mathrm{v}^{2}}\left[\begin{array}{ccc}
1 & \mathrm{v} & 0 \\
\mathrm{v} & 1 & 0 \\
0 & 0 & \frac{1}{2}(1-\mathrm{v})
\end{array}\right]\left\{\begin{array}{c}
\varepsilon_{\mathrm{xx}} \\
\varepsilon_{\mathrm{yy}} \\
2 \varepsilon_{\mathrm{xy}}
\end{array}\right\}
$$

\section{Atau :}

$$
\{\sigma\}=[\mathrm{E}]\{\varepsilon\}
$$

Dengan regangan :

$$
\begin{aligned}
& \left\{\varepsilon_{\mathrm{ML}}\right\}_{\mathrm{i}}=\left[\mathrm{D}_{\mathrm{M}}\right]_{\mathrm{i}} \cdot\left\{\Delta_{\mathrm{M}}\right\}_{\mathrm{i}}
\end{aligned}
$$

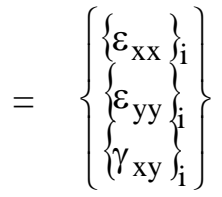

Jadi tegangan :

$$
\begin{aligned}
\left\{\sigma_{\mathrm{ML}}\right\}_{\mathrm{i}} & =\left[\mathrm{E}_{\mathrm{M}}\right]_{\mathrm{i}} \cdot\left\{\varepsilon_{\mathrm{ML}}\right\}_{\mathrm{i}} \\
& =\left\{\begin{array}{l}
\left\{\sigma_{\mathrm{xx}}\right\}_{\mathrm{i}} \\
\left\{\sigma_{\mathrm{yy}}\right\}_{\mathrm{i}} \\
\left.\tau_{\mathrm{xy}}\right\}_{\mathrm{i}}
\end{array}\right\}
\end{aligned}
$$

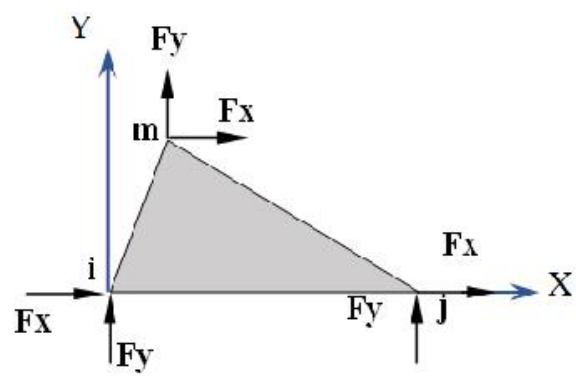

Gambar 4. Gaya Nodal

Menghitung gaya-gaya nodal pada setiap elemen segitiga :

a. Dalam sumbu lokal

$$
\left\{\mathrm{A}_{\mathrm{ML}}\right\}_{\mathrm{i}}=\left[\mathrm{S}_{\mathrm{M}}\right]_{\mathrm{i}} \cdot\left\{\Delta_{\mathrm{M}}\right\}_{\mathrm{i}}
$$

b. Dalam sumbu global

$$
\left\{\mathrm{A}_{\mathrm{MS}}\right\}_{\mathrm{i}}=\left[\mathrm{T}_{\mathrm{M}}\right]_{\mathrm{i}}^{\mathrm{T}} \cdot\left\{\mathrm{A}_{\mathrm{ML}}\right\}_{\mathrm{i}}
$$

$$
\begin{aligned}
& \text { Dengan : } \\
& \left\{\mathrm{A}_{\mathrm{ML}}\right\}_{\mathrm{i}}=\text { Gaya nodal pada }
\end{aligned}
$$

Perakitan matriks kekakuan dari matriks elemen memerlukan proses transformasi koordinat. Yaitu transformasi dari koordinat lokal ke koordinat global, seperti pada gambar 5. Matriks transformasi dapat dilihat pada rumus 10 .

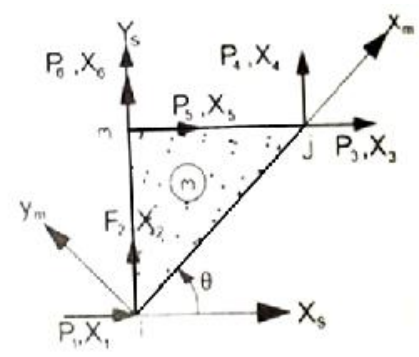

$$
\{P\}_{m}=[k]_{m}\{X\}_{m}
$$

Gambar 5. Matriks Kekakuan Elemen 


$$
\left[\mathrm{T}_{\mathrm{M}}\right]_{\mathrm{i}}=\left[\begin{array}{cccccc}
\cos \theta & \sin \theta & 0 & 0 & 0 & 0 \\
-\sin \theta & \cos \theta & 0 & 0 & 0 & 0 \\
0 & 0 & \cos \theta & \sin \theta & 0 & 0 \\
0 & 0 & -\sin \theta & \cos \theta & 0 & 0 \\
0 & 0 & 0 & 0 & \cos \theta & \sin \theta \\
0 & 0 & 0 & 0 & -\sin \theta & \cos \theta
\end{array}\right]
$$

Sedangkan untuk meghitung matriks kekakuan elemen dalam sumbu lokal sebagai berikut :

$\left[\mathrm{S}_{\mathrm{M}}\right]_{\mathrm{i}}=\left(\left[\mathrm{A}_{\mathrm{M}}\right]_{\mathrm{i}} \times\left[\mathrm{E}_{\mathrm{M}}\right]_{\mathrm{i}} \times\left[\mathrm{D}_{\mathrm{M}}\right]_{\mathrm{i}}\right) \times \Gamma \times \mathrm{t}$

Dengan :

$\left[\mathrm{S}_{\mathrm{M}}\right]_{\mathrm{i}}=$ Matriks kekakuan elemen

$\left[\mathrm{E}_{\mathrm{M}}\right]_{\mathrm{i}}=$ Modulus elastisitas

$\Gamma=$ Luas elemen

$\mathrm{t}=$ Tebal elemen

[AM] dan [DM] adalah komponen koordinat matriks kekakuan dengan :

$\mathrm{D}_{\mathrm{Mi}_{\mathrm{i}}}=\frac{1}{2 \Gamma}\left[\begin{array}{cccccc}\mathrm{b}_{\mathrm{i}} & 0 & \mathrm{~b}_{\mathrm{j}} & 0 & \mathrm{~b}_{\mathrm{m}} & 0 \\ 0 & \mathrm{c}_{\mathrm{i}} & 0 & \mathrm{c}_{\mathrm{j}} & 0 & \mathrm{c}_{\mathrm{m}} \\ \mathrm{c}_{\mathrm{i}} & \mathrm{b}_{\mathrm{i}} & \mathrm{c}_{\mathrm{j}} & \mathrm{b}_{\mathrm{j}} & \mathrm{c}_{\mathrm{m}} & \mathrm{b}_{\mathrm{m}}\end{array}\right]$

$\left[\mathrm{A}_{\mathrm{M}}\right]_{\mathrm{i}}=\left[\mathrm{D}_{\mathrm{M}}\right]_{\mathrm{i}}^{\mathrm{T}}$

\section{DATA DAN ANALISA DATA}

\section{Data Struktur Shear Wall}

Struktur dinding geser yang ditinjau adalah dinding geser type CW2 pada Gedung Kantor Dinas 9 (Sembilan) Lantai Provinsi Riau. Posisi yang ditinjau berada pada As-3 sampai dengan As-5 dan As-A sampai dengan As-C.

Dinding geser (shear wall) Type CW 2 adalah dinding struktur beton bertulang dengan ketebalan eksisting 30 $\mathrm{cm}$ dengam lebar $3 \mathrm{~m}$ dan tinggi $42.5 \mathrm{~m}$ dari basement hingga lantai 9 (sembilan) pada bangunan gedung ini.

a. Geometri Struktur Shear Wall
1). Tebal dinding
$=0,30 \mathrm{~m}$
2).Lebar dinding
$=3 \mathrm{~m}$
3). Tinggi dinding geser :
Pada basement $=4,5 \mathrm{~m}$
Pada lantai dasar $\quad=6 \mathrm{~m}$
Pada lantai $1 \mathrm{sd} 8=4 \mathrm{~m}$
Tinggi total
$=42,5 \mathrm{~m}$

b. Material komponen struktur

1). Mutu beton, $f_{c}$, = $30 \mathrm{MPa}$

2). Modulus elastisitas beton,

$$
\begin{aligned}
\mathrm{E}_{\mathrm{c}} & =4700 \sqrt{ } 30 \\
& =25742,96 \mathrm{MPa} \\
& =25742960 \mathrm{kN} / \mathrm{m}^{2}
\end{aligned}
$$

3). Rasio poisson, $v=0,2$

4). Modulus geser, $G$

$$
\begin{aligned}
\mathrm{G} & =\mathrm{E}_{\mathrm{c}} /(2(1+\mathrm{v})) \\
& =10726,23 \mathrm{MPa} \\
& =10726230 \mathrm{kN} / \mathrm{m}^{2}
\end{aligned}
$$

5). Massa per unit volume, $\mathrm{m}$ $\mathrm{m}=2,4 \mathrm{kN} / \mathrm{m}^{3}$ 


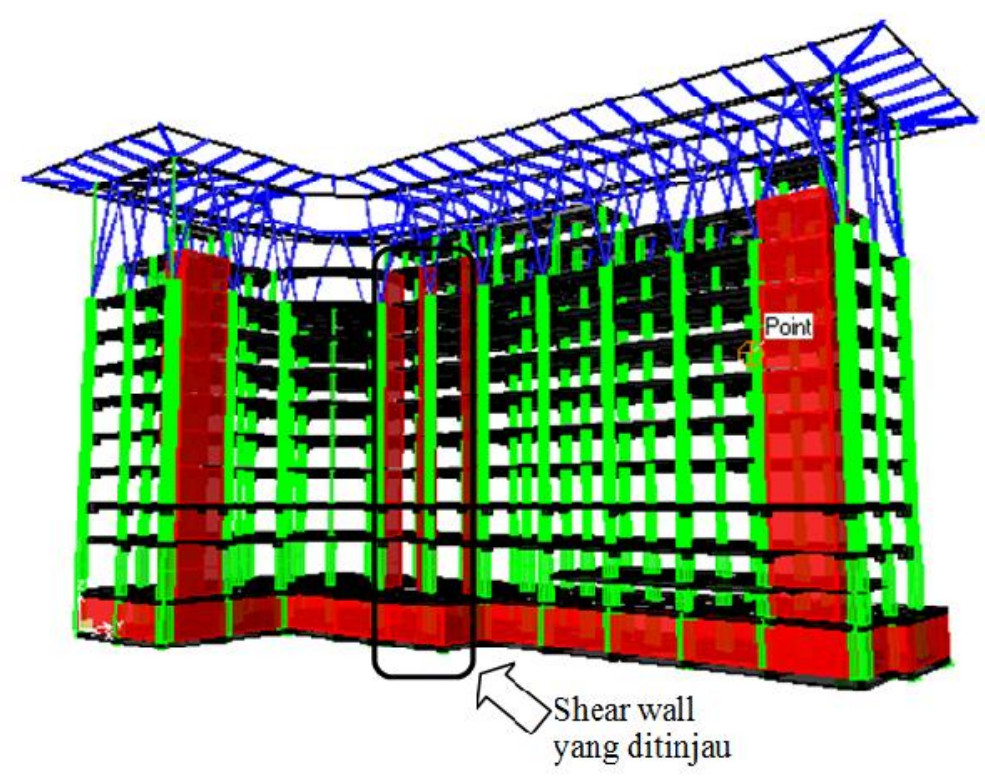

Gambar 6. Bentuk Struktur Gedung
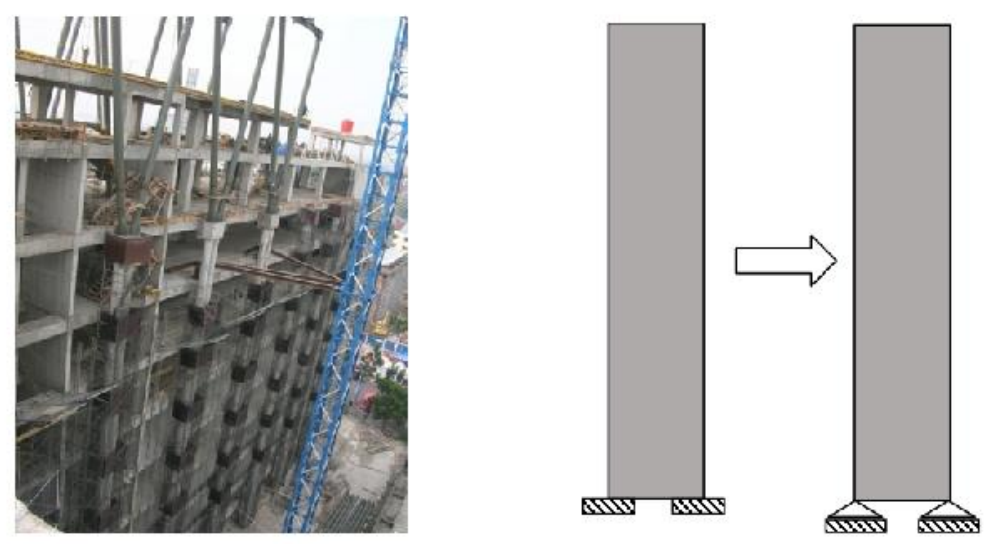

Gambar 7. Pemodelan Dinding Geser

\section{Pembebanan Lateral}

Dalam penelitian ini, pembebanan dinding geser adalah pembebanan lateral. Dinding geser yang ditinjau adalah dinding geser pada posisi AS4A. Dengan demikian untuk pembebanan dinding geser pada AS-4 ini dihitung berdasarkan luasan lantai dari AS-3 sampai dengan AS-5. Ilustrasi area pembebanan gravitasi dapat dilihat pada gambar 8 .
Perhitungan pembebanan dinding geser dilakukan beberapa langkah sebagai berikut :

a. Menghitung lump mass atau beban gravitasi tergumpal. Beban lump mass ini berasal dari beban gravitasi akibat beban mati dan beban hidup. Beban lump mass dihitung sebagai berikut :
1). Menghitung berat sendiri struktur tiap lantai
2). Menghitung berat mati tambahan (Superimpossed Dead Load / SDL)


3). Menghitung beban hidup yang bekerja pada lantai. Sesuai dengan standard peraturan beban hidup sebesar $250 \mathrm{~kg} / \mathrm{m}^{2}$.
Beban gravitasi adalah beban mati ditambah beban hidup. Hasil perhitungan beban gravitasi berupa lump mass dalam tabel 1.

(3)

(4)

(5)

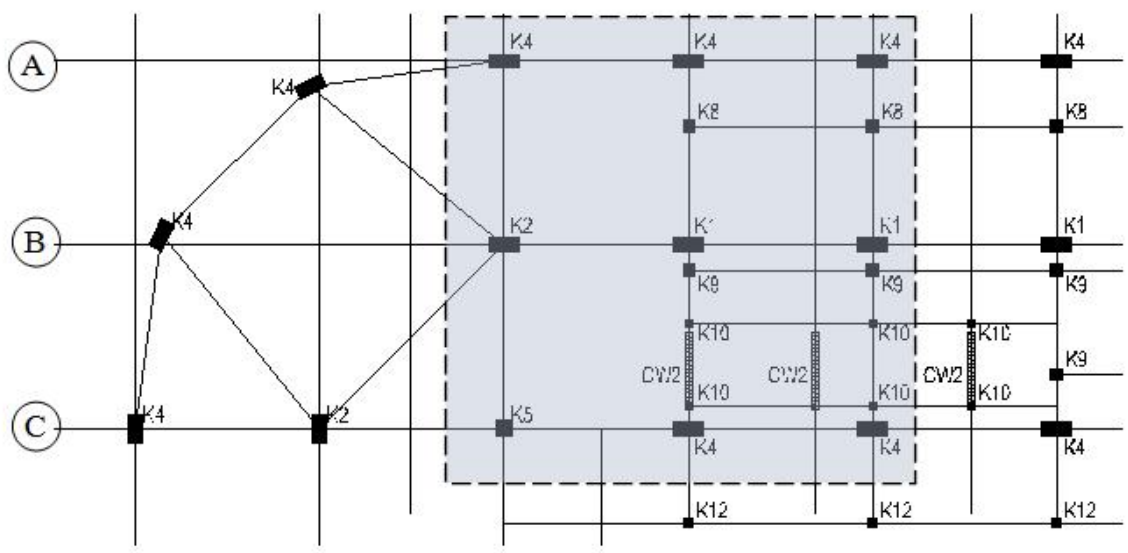

Gambar 8. Area Pembebanan Dinding Geser

Tabel 1. Beban Gravitasi

\begin{tabular}{cccc}
\hline $\begin{array}{c}\text { No. } \\
\text { Lantai }\end{array}$ & $\begin{array}{c}\text { Beban Mati } \\
{[\mathbf{k g}]}\end{array}$ & $\begin{array}{c}\text { Beban Hidup } \\
{[\mathbf{k g}]}\end{array}$ & $\begin{array}{c}\text { Gravitasi }(\mathbf{W i}) \\
{[\mathbf{k g}]}\end{array}$ \\
\hline 9 & $129.537,92$ & $28.183,16$ & $157.721,08$ \\
8 & $311.187,78$ & $50.941,61$ & $362.129,39$ \\
7 & $271.233,16$ & $48.496,81$ & $319.729,97$ \\
6 & $271.233,16$ & $48.496,81$ & $319.729,97$ \\
5 & $271.233,16$ & $48.496,81$ & $319.729,97$ \\
4 & $271.521,16$ & $48.496,81$ & $320.017,97$ \\
3 & $271.809,16$ & $48.496,81$ & $320.305,97$ \\
2 & $271.809,16$ & $48.496,81$ & $320.305,97$ \\
1 & $331.110,28$ & $48.547,60$ & $379.657,88$ \\
Dasar & $390.412,44$ & $91.028,97$ & $481.441,41$ \\
Basement & 0 & 0 & 0 \\
\hline
\end{tabular}

b. Menentukan kategori seismik :

1). Kategori resiko bangunan gedung dan non gedung untuk beban gempa. Berdasarkan tabel 2 pada SNI 1726-2012, diperoleh kategori resiko adalah II.

2). Faktor keutamaan gempa, Ie. Berdasarkan kategori resiko bangunan di atas (yaitu kategori II), maka faktor keutamaan gempa pada tabel 3 pada SNI 1726-2012, diperoleh $\mathrm{I}_{\mathrm{e}}=1$.
Tabel 2. Kategori Resiko Gedung dan Non Gedung

\begin{tabular}{lc}
\hline \multicolumn{1}{c}{ Jenis Pemanfaatan } & $\begin{array}{c}\text { Kategori } \\
\text { Risiko }\end{array}$ \\
\hline Semua gedung dan & \\
struktur lain, kecuali & \\
yang termasuk dalam & \multicolumn{1}{c}{ II } \\
kategori risiko I, III, IV, & \\
termasuk, tapi tidak & \\
dibatasi untuk: & \\
Gedung perkantoran & \\
\hline
\end{tabular}


Tabel 3. Faktor Keutamaan Gedung

\begin{tabular}{cc}
\hline $\begin{array}{c}\text { Kategori } \\
\text { Resiko }\end{array}$ & $\begin{array}{c}\text { Faktor Keutamaan } \\
\text { Gempa, } \boldsymbol{I}_{\boldsymbol{e}}\end{array}$ \\
\hline I atau II & 1.0 \\
III & 1.25 \\
IV & 1.50 \\
\hline
\end{tabular}

3). Tentukan klasifikasi situs tanah (SDC). Berdasarkan penyelidikan tanah N-SPT, dapat diketahui bahwa kondisi Tanah Sedang (SD). Sesuai klasifikasi situs tanah SNI 1726-2012, bahwa nilai $\mathrm{N}$ antara 15 sampai dengan 50 adalah tanah sedang (SD).

4). Tentukan nilai $S_{s}$ dan $S_{1}$ berdasarkan wilayah gempa Kota Pekanbaru. Berdasarkan data Puskim nilai $\mathrm{S}_{\mathrm{s}}=0,435$ dan $\mathrm{S}_{1}=$ 0,273 . c. Tentukan Nilai $\mathrm{R}$ untuk sistem penahan gaya gempa, berdasarkan tabel 9 SNI 1726-2012, struktur dinding geser adalah kategori D. Untuk dinding geser beton betulang khusus dengan nilai $\mathrm{R}=7$.

d. Tentukan nilai Perioda fundamental pendekatan $\left(\mathrm{T}_{\mathrm{a}}\right)$

$$
\mathrm{T}_{\mathrm{a}}=\mathrm{C}_{\mathrm{t}} \cdot \mathrm{n}_{\mathrm{n}}^{\mathrm{x}}
$$

$$
\begin{aligned}
& \text { Dengan : } \\
& \mathrm{h}_{\mathrm{n}}= \text { Tinggi total dinding geser } \\
& \mathrm{C}_{\mathrm{t}}= \text { Koefisien ditentukan oleh } \\
& \text { SNI 1726-2012 } \\
& \mathrm{x}= \text { Koefisien ditentukan oleh } \\
& \text { SNI 1726-2012 }
\end{aligned}
$$

Tabel 4. Nilai parameter perioda pendekatan $C_{t}$ dan $x$

\begin{tabular}{llc}
\hline \multicolumn{1}{c}{ Tipe Struktur } & $\mathbf{C}_{\mathbf{t}}$ & $\mathbf{X}$ \\
\hline Rangka baja pemikul momen & $0,0724^{\mathrm{a}}$ & 0,8 \\
\hline Rangka beton pemikul momen & $0,0466^{\mathrm{a}}$ & 0,9 \\
\hline Rangka baja dengan bresing eksentris & $0,0731^{\mathrm{a}}$ & 0,75 \\
\hline $\begin{array}{l}\text { Rangka baja dengan bresing terkekang } \\
\text { terhadap tekuk }\end{array}$ & $0,0731^{\mathrm{a}}$ & 0,75 \\
\hline Semua sistem struktur lainnya & $0,0488^{\mathrm{a}}$ & 0,75 \\
\hline
\end{tabular}

Dari tabel 4 maka diperoleh :

$$
\begin{array}{ll}
\mathrm{h}_{\mathrm{n}} & =42,5 \mathrm{~m} \\
\mathrm{C}_{\mathrm{t}} & =0,0488 \\
\mathrm{x} & =0,75 \\
\mathrm{~T}_{\mathrm{a}} & =0,0488 \times 42,5^{0,75} \\
& =0,812 \text { detik }
\end{array}
$$

e. Tentukan nilai $\mathrm{C}_{\mathrm{s}}$ (koefisien respons seismik) yang ditentukan dengan pasal 7.8.11 SNI 1726-2012

$$
\mathrm{C}_{\mathrm{s}}=\frac{\mathrm{S}_{\mathrm{DS}}}{\left(\frac{\mathrm{R}}{\mathrm{I}_{\mathrm{e}}}\right)}
$$

f. Menghitung gaya geser dasar atau $\mathrm{V}_{\text {base }}$ sebagai berikut :

$$
\begin{aligned}
\mathrm{C}_{\mathrm{s}} & =\mathrm{C}_{\mathrm{s}} \times \mathrm{W}_{\text {total }} \\
& =0,059 \times 3.300 .769,57 \\
& =195.630,04 \mathrm{~kg} \\
& =1.956,30 \mathrm{kN}
\end{aligned}
$$

g. Menghitung faktor distribusi vertikal $\left(\mathrm{C}_{\mathrm{vx}}\right)$ :

$$
\mathrm{C}_{\mathrm{vx}}=\frac{\mathrm{w}_{\mathrm{x}} \cdot \mathrm{h}_{\mathrm{x}}^{\mathrm{k}}}{\sum_{\mathrm{i}=1}^{\mathrm{n}} \mathrm{w}_{\mathrm{i}} \cdot \mathrm{h}^{\mathrm{k}}{ }_{\mathrm{i}}^{\mathrm{k}}}
$$


h. Menghitung gaya gempa lateral $\left(\mathrm{F}_{\mathrm{x}}\right)$ tiap lantai :

$\mathrm{F}_{\mathrm{x}}=\mathrm{C}_{\mathrm{vX}} \cdot \mathrm{V}_{\text {base }}$

Gaya gempa lateral tiap lantai $\left(\mathrm{F}_{\mathrm{x}}\right)$ disajikan pada tabel 5 .
Beban-beban tersebut selanjutnya dipasangkan pada shear wall sesuai dengan nomor lantainya. Kemudian perhitungan tegangan yang terjadi pada shear wall dilakukan dengan analisis plane stress.

Tabel 5. Gaya gempa lateral tiap lantai

\begin{tabular}{ccc}
\hline No. Lantai & $\mathbf{C}_{\mathbf{v} \mathbf{x}}$ & $\mathbf{F}_{\mathbf{x}}(\mathbf{k N})$ \\
\hline 9 & 0,090799 & 177,63 \\
8 & 0,188855 & 369,46 \\
7 & 0,149419 & 292,31 \\
6 & 0,132095 & 258,42 \\
5 & 0,114771 & 224,53 \\
4 & 0,097535 & 190,81 \\
3 & 0,080268 & 157,03 \\
2 & 0,062912 & 123,08 \\
1 & 0,053999 & 105,64 \\
Dasar & 0,029347 & 57,41 \\
Basement & 0 & 0 \\
Jumlah & & $\Sigma \mathrm{F}_{\mathbf{x}}=\mathbf{1 . 9 5 6 , 3 0}$ \\
\hline
\end{tabular}

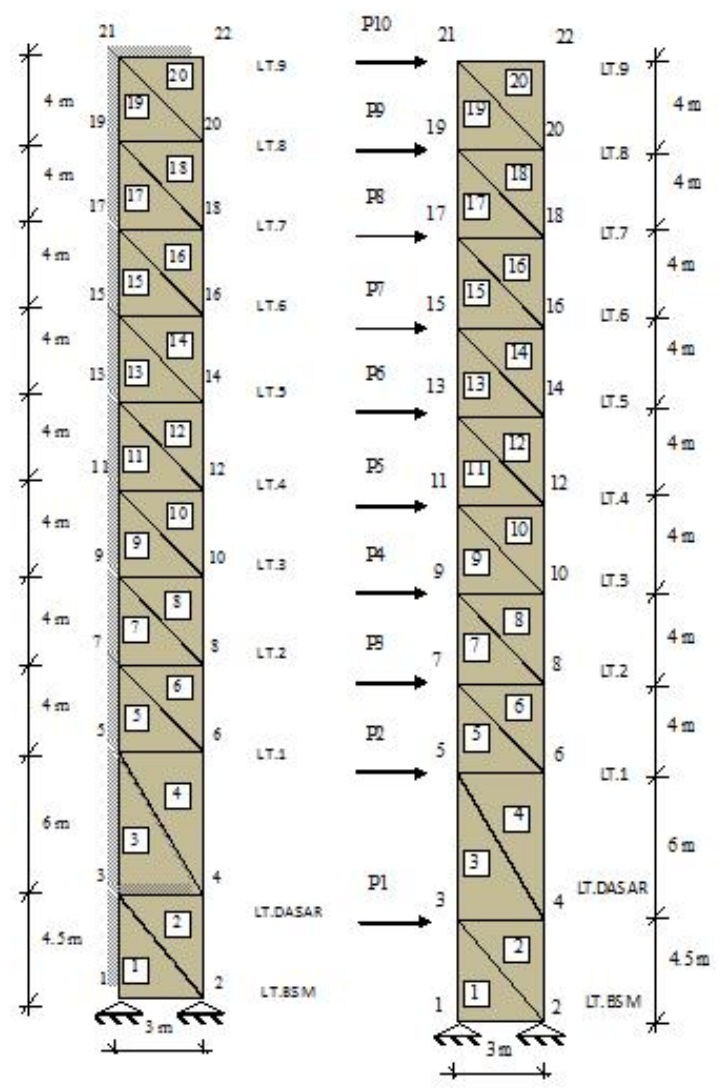

Gambar 9. Pemodelan, Meshing dan Pembebanan Dinding Geser 


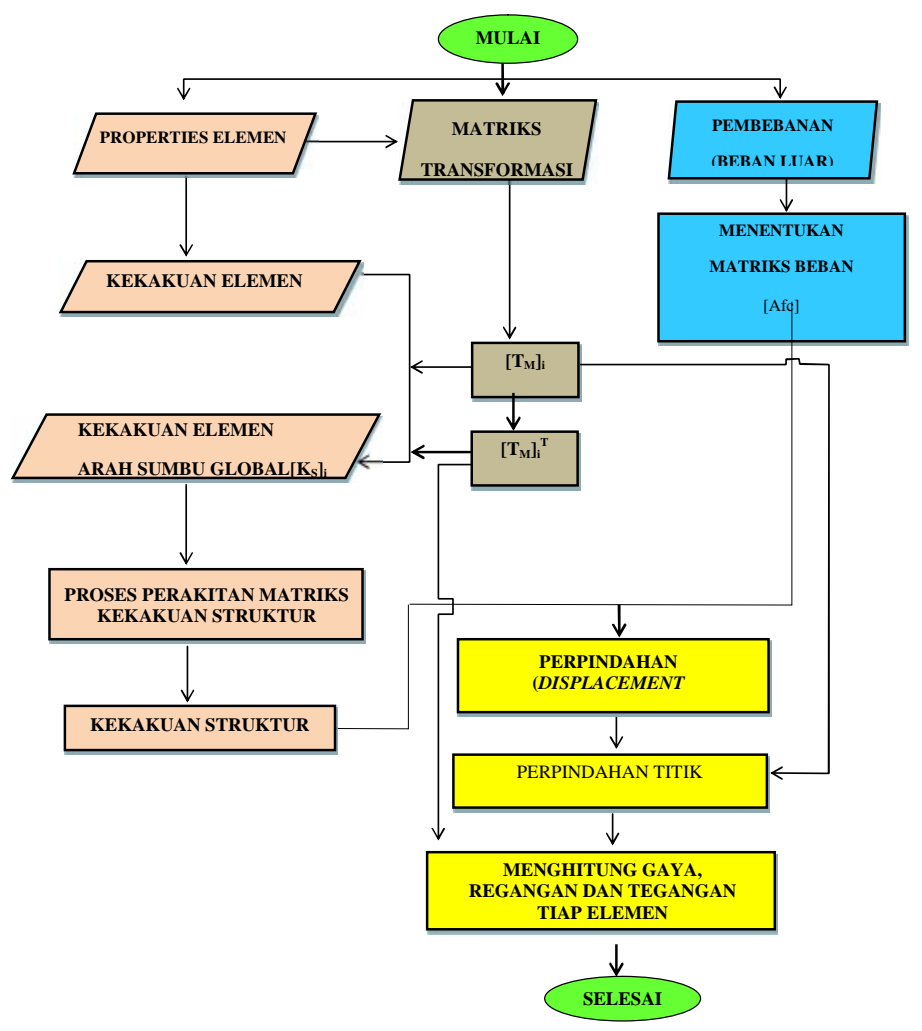

Gambar 10. Bagan Alir Analisis Plane Stress

\section{HASIL DAN PEMBAHASAN}

\section{Pemodelan Elemen Shear Wall}

Analisis struktur dilakukan untuk menghitung displacement dan gayagaya dalam yang terjadi pada struktur. Gaya-gaya dalam ini diperoleh untuk menghitung tegangan yang terjadi pada elemen struktur.

Dalam melakukan analisis tegangan bidang, elemen bidang dinding geser dibagi menjadi elemen segitiga. Hal ini disebut dengan meshing. Kemudian pada masing-masing joint segitiga akan mengalami perpindahan dalam arah X dan arah Y. Artinya pada tiap joint hanya anda 2 perpindahan $(\mathrm{DOF}=2)$. Ilustrasi meshing dan DOF dapat dilihat pada gambar 11 .

\section{Analisis Plane Stress Dinding Geser}

Untuk mempermudah perhitungan tegangan-tegangan yang terjadi pada bidang dinding geser (shear wall), maka dibuat program analisis plane stress. Dalam program ini terdiri dari beberapa function dan 1 (satu) file utama. File utama dalam program ini juga berfungsi sebagai input yang akan dihitung dengan fungsi-fungsi (function) yang ada. Input yang dimasukan dalam program ini yaitu mutu beton, modulus elastisitas, poisson ratio, modulus geser, tebal dinding geser, geometri struktur dan pembebanan gaya lateral.

Setelah melalui proses run Program Matlab, maka didapatkan hasil berupa perpindahan titik (displacement), gaya pada titik kumpul bidang dan tegangan-tegangan bidang yang disajikan pada tabel 6 .

Untuk validasi perhitungan program Matlab, maka perhitungan plane stress dilakukan dengan 2 (dua) cara. Yaitu analisis metode elemen hingga secara manual dan analisis dengan software elemen hingga. 


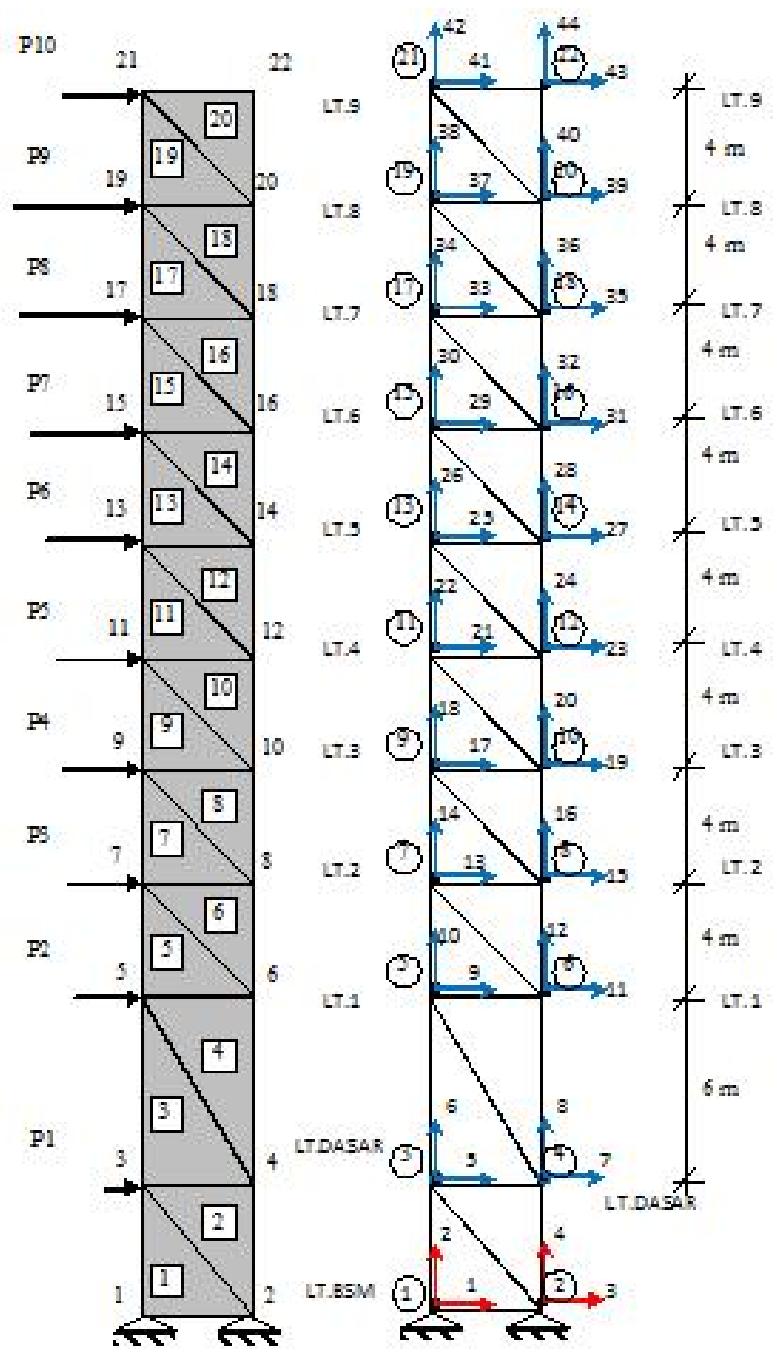

Gambar 11. Diskretisasi dan DOF Global

Tabel 6. Perpindahan Titik dan Gaya

\begin{tabular}{ccccc}
\hline Joint & $\mathbf{X}[\mathbf{m}]$ & $\mathbf{Y}[\mathbf{m}]$ & $\mathbf{F x}$ & $\mathbf{F y}$ \\
\hline $\mathbf{1}$ & 0 & 0 & $-9120,69400$ & $-18680,02$ \\
$\mathbf{2}$ & 0 & 0 & 7164,39400 & 18680,02 \\
$\mathbf{3}$ & 0,00596 & 0,00339 & 57,41100 & 0 \\
$\mathbf{4}$ & 0,00609 & $-0,00340$ & 0 & 0 \\
$\mathbf{5}$ & 0,02607 & 0,00599 & 105,63800 & 0 \\
$\mathbf{6}$ & 0,02617 & $-0,00610$ & 0 & 0 \\
$\mathbf{7}$ & 0,04573 & 0,00804 & 123,07600 & 0 \\
$\mathbf{8}$ & 0,04583 & $-0,00820$ & 0 & 0 \\
$\mathbf{9}$ & 0,07029 & 0,00965 & 157,02800 & 0 \\
$\mathbf{1 0}$ & 0,07038 & $-0,00990$ & 0 & 0 \\
$\mathbf{1 1}$ & 0,09860 & 0,01085 & 190,80800 & 0 \\
$\mathbf{1 2}$ & 0,09867 & $-0,01110$ & 0 & 0 \\
$\mathbf{1 3}$ & 0,12959 & 0,01169 & 224,52700 & 0 \\
$\mathbf{1 4}$ & 0,12966 & $-0,01200$ & 0 & 0 \\
$\mathbf{1 5}$ & 0,16236 & 0,01221 & 258,41800 & 0 \\
\hline
\end{tabular}


Raharja, S., Suryanita, R., Djauhari, Z./ Analisis Tegangan Bidang/ pp. 58 - 76

\begin{tabular}{ccccc}
\hline Joint & $\mathbf{X}[\mathbf{m}]$ & $\mathbf{Y}[\mathbf{m}]$ & $\mathbf{F x}$ & $\mathbf{F y}$ \\
\hline $\mathbf{1 6}$ & 0,16241 & $-0,01260$ & 0 & 0 \\
$\mathbf{1 7}$ & 0,19613 & 0,01249 & 292,30900 & 0 \\
$\mathbf{1 8}$ & 0,19616 & $-0,01290$ & 0 & 0 \\
$\mathbf{1 9}$ & 0,23032 & 0,01260 & 369,45700 & 0 \\
$\mathbf{2 0}$ & 0,23033 & $-0,01300$ & 0 & 0 \\
$\mathbf{2 1}$ & 0,26453 & 0,01262 & 177,63100 & 0 \\
$\mathbf{2 2}$ & 0,26452 & $-0,01300$ & 0 & 0 \\
\hline
\end{tabular}

Tabel 7. Tegangan Bidang Elemen

\begin{tabular}{cccc}
\hline Elemen & $\begin{array}{c}\sigma_{\mathbf{x x}} \\
{\left[\mathbf{k N} / \mathbf{m}^{2}\right]}\end{array}$ & $\begin{array}{c}\sigma_{\mathbf{v v}} \\
{\left[\mathbf{k N} / \mathbf{m}^{2}\right]}\end{array}$ & $\begin{array}{c}\tau_{\mathbf{x v}} \\
{\left[\mathbf{k N} / \mathbf{m}^{2}\right]}\end{array}$ \\
\hline $\mathbf{1}$ & 4039,579 & 20197,894 & 14208,841 \\
$\mathbf{2}$ & $-2945,671$ & $-20197,894$ & $-9861,507$ \\
$\mathbf{3}$ & 3460,156 & 11831,241 & 11579,456 \\
$\mathbf{4}$ & $-1492,500$ & $-11831,241$ & $-7359,702$ \\
$\mathbf{5}$ & 3666,138 & 13961,949 & 9441,522 \\
$\mathbf{6}$ & $-1944,933$ & $-13961,949$ & $-5456,519$ \\
$\mathbf{7}$ & 3039,177 & 10958,602 & 7709,029 \\
$\mathbf{8}$ & $-1430,569$ & $-10958,602$ & $-3997,528$ \\
$\mathbf{9}$ & 2401,363 & 8201,057 & 6065,687 \\
$\mathbf{1 0}$ & $-983,473$ & $-8201,057$ & $-2703,135$ \\
$\mathbf{1 1}$ & 1805,681 & 5744,714 & 4545,392 \\
$\mathbf{1 2}$ & $-614,135$ & $-5744,714$ & $-1606,858$ \\
$\mathbf{1 3}$ & 1264,400 & 3647,959 & 3179,425 \\
$\mathbf{1 4}$ & $-334,350$ & $-3647,959$ & $-739,839$ \\
$\mathbf{1 5}$ & 789,104 & 1969,311 & 1998,825 \\
$\mathbf{1 6}$ & $-156,161$ & $-1969,311$ & $-133,501$ \\
$\mathbf{1 7}$ & 390,785 & 765,420 & 1036,419 \\
$\mathbf{1 8}$ & $-117,183$ & $-765,420$ & 179,331 \\
$\mathbf{1 9}$ & 65,261 & 146,800 & 284,634 \\
$\mathbf{2 0}$ & $-82,575$ & $-146,800$ & 110,100 \\
\hline & & &
\end{tabular}

\section{Validasi Perhitungan Plane Stress}

Setelah validasi perhitungan manual dilakukan, selanjutnya validasi perhitungan dengan menggunakan software finite element. Analisis plane stress dengan menggunakan software ini dapat dilihat sebagai berikut : a. Mendefinisikan material

1). Mutu beton, $\mathrm{f}_{\mathrm{c}}{ }^{\prime}=30 \mathrm{MPa}$

2). Angka poisson, $v=0,2$

3). Modulus elastisitas beton, $E_{c}$

$$
\begin{aligned}
\mathrm{E}_{\mathrm{c}} & =4700 \sqrt{\left(\mathrm{f}_{\mathrm{c}}{ }^{\prime}\right)} \\
& =25742,96 \mathrm{MPa}
\end{aligned}
$$


4). Modulus geser, $\mathrm{G}$

$$
\begin{aligned}
\mathrm{G} & =\mathrm{E}_{\mathrm{c}} /(2 \times(1+\mathrm{v})) \\
& =10726,23 \mathrm{MPa}
\end{aligned}
$$

b. Menentukan dimensi penampang shear wall

Menentukan dimensi penampang yang digunakan, yaitu plat dinding geser yang memiliki ketebalan eksisting $30 \mathrm{~cm}$. Caranya dengan mendefinisikan area section properties.

c. Pemodelan struktur shear wall dan pembebanan gempa lateral

Kemudian proses pemodelan dapat dilakukan. Pemodelan shear wall sesuai dengan data geometri struktur yang telah ditentukan sebelumnya. Pembebanan gempa lateral diberikan pada joint tiap lantai, sehingga menghasilkan pemodelan dan pembeban struktur shear wall ditampilkan pada Gambar 12.

Setelah langkah-langkah pendefinisian material, menentukan penampang, pemodelan dan pembebanan struktur dilakukan, maka proses analisis dapat dilakukan dengan run analysis pada software finite element. Hasil perhitungan analisis yang diperlukan adalah perpindahan titik (joint displacement) dan tegangantegangan bidang yang terjadi pada dinding geser atau shear wall.

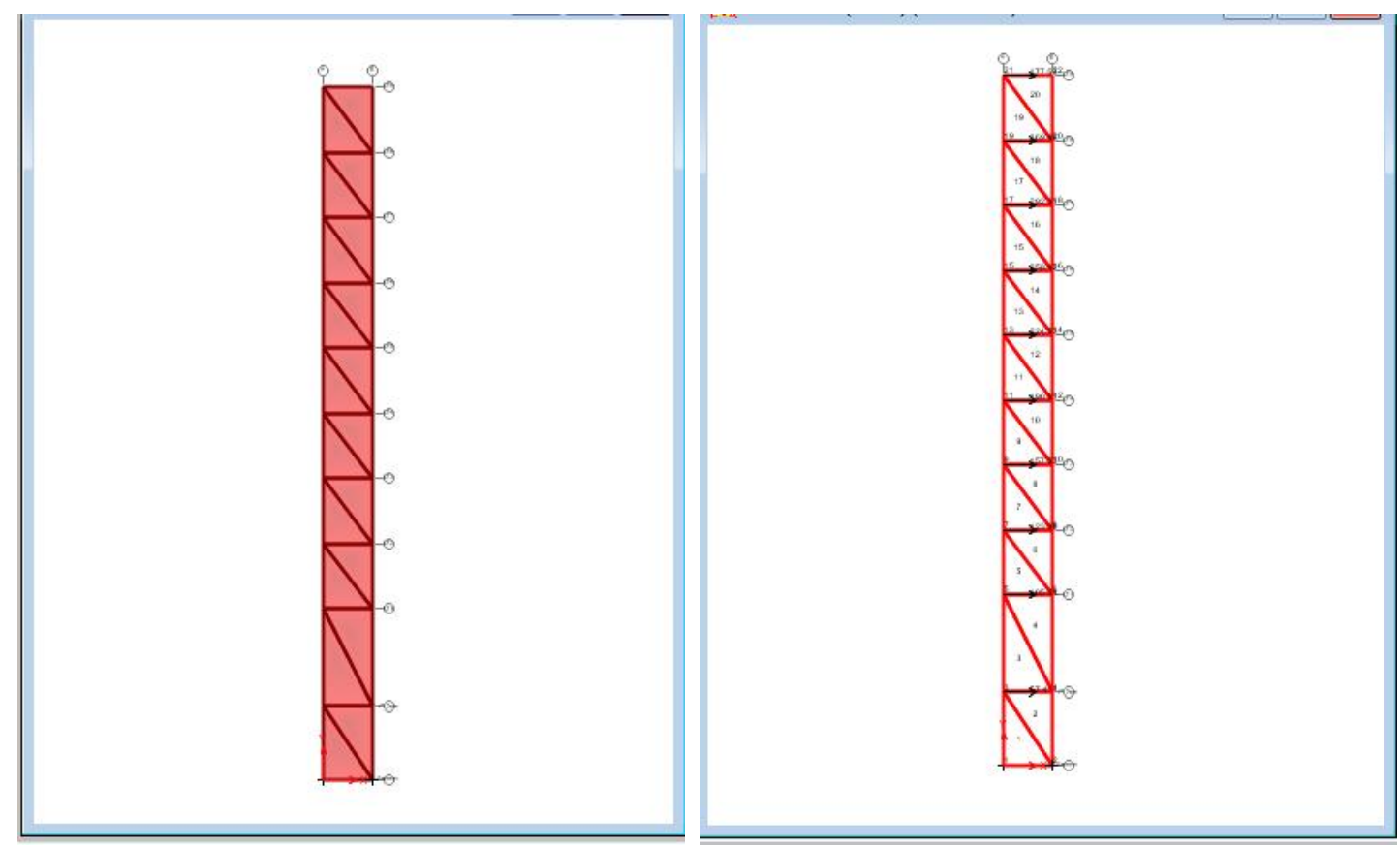

Gambar 12. Pemodelan dan Pembebanan Lateral pada Shear Wall 

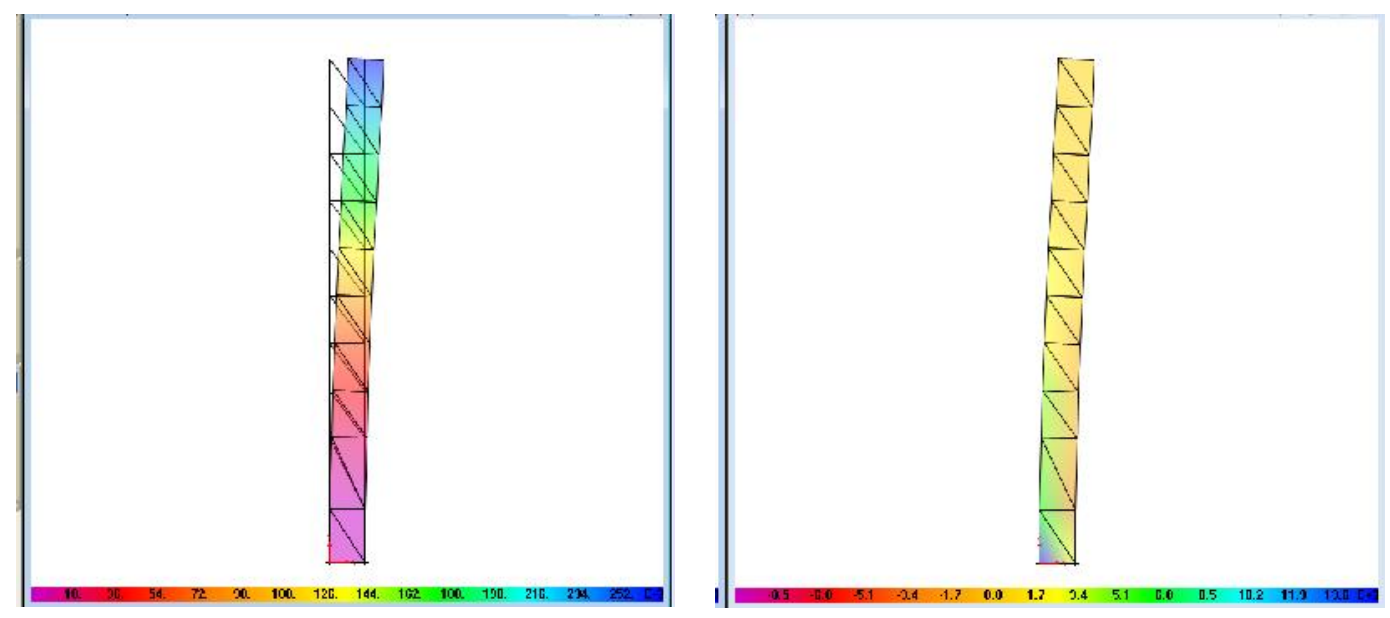

Gambar 13. Deformasi Shear Wall dan Tegangan Geser Bidang $\left(\tau_{\mathrm{xy}}\right)$

Selanjutnya hasil analisis plane stress dengan mengggunakan Program Matlab dapat divalidasi dengan Software Finite Element. Perbandingan hasil perhitungan antara analisis menggunakan Matlab dengan Software Finite Element, disajikan pada tabel 8.

Dari tabel 8 dapat dilihat bahwa hasil perhitungan kedua program adalah sama. Pada joint 1 dan 2 tidak terjadi perpindahan, karena kedua joint tersebut adalah perletakan sendi. Pada gambar 14 ditampilkan grafik perpindahan (displacement) titik untuk arah $\mathrm{x}$ dan arah y.

Dari gambar 14 dapat dilihat bahwa untuk besar perpindahan (displacement) arah $\mathrm{x}$ pada kedua program adalah sama.

Tabel 8. Perbandingan hasil displacement

\begin{tabular}{ccccc}
\hline \multirow{2}{*}{ Joint } & \multicolumn{2}{c}{ Pogram Matlab } & \multicolumn{2}{c}{ Software } \\
\cline { 2 - 5 } & $\mathbf{X}[\mathbf{m}]$ & $\mathbf{Y}[\mathbf{m}]$ & $\mathbf{X}[\mathbf{m}]$ & $\mathbf{Y}[\mathbf{m}]$ \\
\hline 1 & 0 & 0 & 0 & 0 \\
2 & 0 & 0 & 0 & 0 \\
3 & 0,0060 & 0,0034 & 0,0060 & 0,0034 \\
4 & 0,0061 & $-0,0034$ & 0,0061 & $-0,0034$ \\
5 & 0,0261 & 0,0060 & 0,0261 & 0,0060 \\
6 & 0,0262 & $-0,0061$ & 0,0262 & $-0,0061$ \\
7 & 0,0457 & 0,0080 & 0,0457 & 0,0080 \\
8 & 0,0458 & $-0,0082$ & 0,0458 & $-0,0082$ \\
9 & 0,0703 & 0,0096 & 0,0703 & 0,0096 \\
10 & 0,0704 & $-0,0099$ & 0,0704 & $-0,0099$ \\
11 & 0,0986 & 0,0108 & 0,0986 & 0,0108 \\
12 & 0,0987 & $-0,0111$ & 0,0987 & $-0,0111$ \\
13 & 0,1296 & 0,0117 & 0,1296 & 0,0117 \\
14 & 0,1297 & $-0,0120$ & 0,1297 & $-0,0120$ \\
15 & 0,1624 & 0,0122 & 0,1624 & 0,0122 \\
16 & 0,1624 & $-0,0126$ & 0,1624 & $-0,0126$ \\
17 & 0,1961 & 0,0125 & 0,1961 & 0,0125 \\
18 & 0,1962 & $-0,0129$ & 0,1962 & $-0,0129$ \\
19 & 0,2303 & 0,0126 & 0,2303 & 0,0126 \\
20 & 0,2303 & $-0,0130$ & 0,2303 & $-0,0130$ \\
21 & 0,2645 & 0,0126 & 0,2645 & 0,0126 \\
22 & 0,2645 & $-0,0130$ & 0,2645 & $-0,0130$ \\
\hline
\end{tabular}




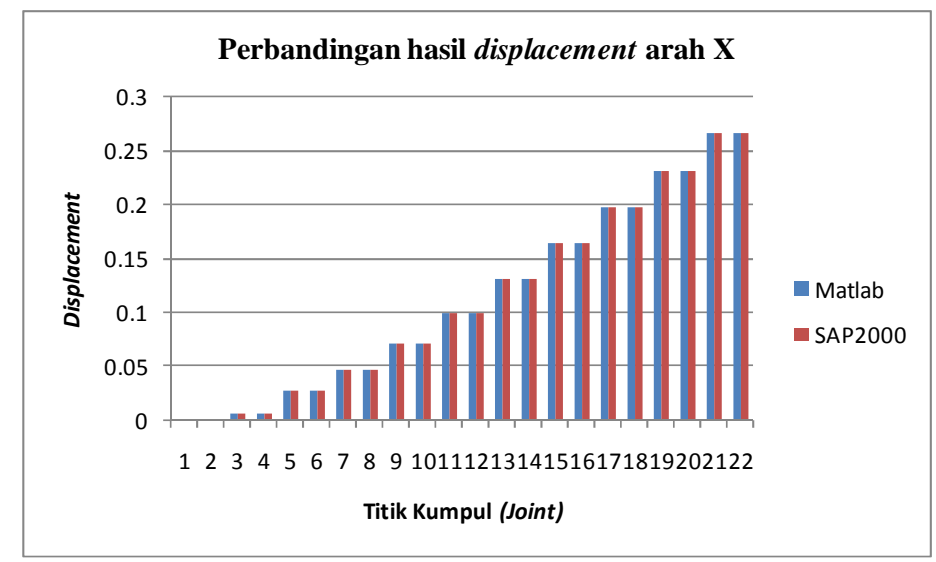

Gambar 14. Grafik Displacement Arah x

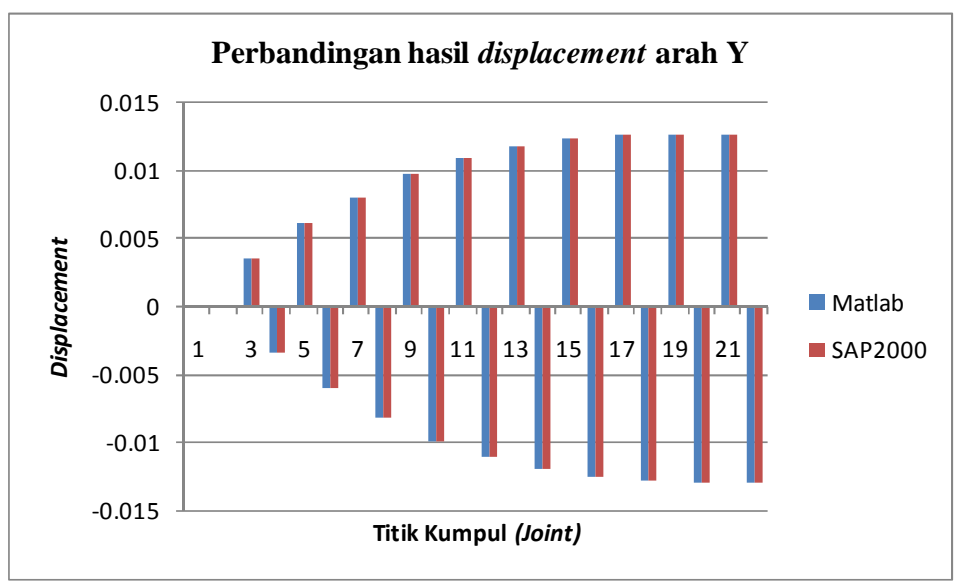

Gambar 15. Grafik displacement arah y

Dari gambar 15 juga menghasilkan besar perpindahan (displacement) arah y pada kedua program adalah sama.

Dengan demikian analisis perhitungan untuk perpindahan titik (joint displacement) sudah benar atau valid. Selanjutnya analisis tegangantegangan bidang (plane stress) dengan menggunakan software finite element dapat dilihat pada tabel 9 .

Perbandingan tegangan-tegangan elemen bidang dinding geser yang dihasilkan oleh kedua metode disajikan pada tabel 10 .

Untuk perhitungan plane stress dengan menggunakan Matlab memiliki nilai akurasi yang baik, dan teruji dengan hasil Software Finite Element. 
Raharja, S., Suryanita, R., Djauhari, Z./ Analisis Tegangan Bidang/ pp. 58 - 76

Tabel 9. Tegangan bidang

\begin{tabular}{|c|c|c|c|}
\hline \multirow[b]{2}{*}{ Elemen } & \multicolumn{3}{|c|}{ Tegangan Bidang dengan Software } \\
\hline & $\begin{array}{c}\sigma_{\mathrm{xx}} \\
{\left[\mathrm{kN} / \mathrm{m}^{2}\right]}\end{array}$ & $\begin{array}{c}\sigma_{\mathrm{yy}} \\
{\left[\mathrm{kN} / \mathbf{m}^{2}\right]}\end{array}$ & $\begin{array}{c}\tau_{\mathrm{xy}} \\
{\left[\mathrm{kN} / \mathrm{m}^{2}\right]}\end{array}$ \\
\hline 1 & 4039,58 & 20197,89 & 14208,84 \\
\hline 2 & $-2945,67$ & $-20197,89$ & $-9861,51$ \\
\hline 3 & 3460,16 & 11831,24 & 11579,46 \\
\hline 4 & $-1492,5$ & $-11831,24$ & $-7359,7$ \\
\hline 5 & 3666,14 & 13961,95 & 9441,52 \\
\hline 6 & $-1944,93$ & $-13961,95$ & $-5456,52$ \\
\hline 7 & 3039,18 & 10958,6 & 7709,03 \\
\hline 8 & $-1430,57$ & $-10958,6$ & $-3997,53$ \\
\hline 9 & 2401,36 & 8201,06 & 6065,69 \\
\hline 10 & $-983,47$ & $-8201,06$ & $-2703,14$ \\
\hline 11 & 1805,68 & 5744,71 & 4545,39 \\
\hline 12 & $-614,14$ & $-5744,71$ & $-1606,86$ \\
\hline 13 & 1264,4 & 3647,96 & 3179,42 \\
\hline 14 & $-334,35$ & $-3647,96$ & $-739,84$ \\
\hline 15 & 789,1 & 1969,31 & 1998,82 \\
\hline 16 & $-156,16$ & $-1969,31$ & $-133,5$ \\
\hline 17 & 390,78 & 765,42 & 1036,42 \\
\hline 18 & $-117,18$ & $-765,42$ & 179,33 \\
\hline 19 & 65,26 & 146,8 & 284,63 \\
\hline 20 & $-82,58$ & $-146,8$ & 110,1 \\
\hline
\end{tabular}

Tabel 10. Perbandingan Hasil Analisis Tegangan Bidang (Plane Stress)

\begin{tabular}{ccccccc}
\hline \multirow{2}{*}{ Elemen n } & \multicolumn{3}{c}{ Program Matlab } & \multicolumn{3}{c}{ Software Finite Element } \\
\cline { 2 - 7 } & $\sigma_{\mathrm{xx}}\left[\mathbf{k N} / \mathbf{m}^{2}\right]$ & $\sigma_{\mathrm{yv}}\left[\mathbf{k N} / \mathbf{m}^{2}\right]$ & $\tau_{\mathrm{xy}}\left[\mathbf{k N} / \mathbf{m}^{2}\right]$ & $\sigma_{\mathrm{xx}}\left[\mathbf{k N} / \mathbf{m}^{2}\right]$ & $\sigma_{\mathrm{vy}}\left[\mathbf{k N} / \mathbf{m}^{2}\right]$ & $\tau_{\mathrm{xv}}\left[\mathbf{k N} / \mathbf{m}^{2}\right]$ \\
\hline 1 & 4039,579 & 20197,894 & 14208,841 & 4039,58 & 20197,89 & 14208,84 \\
2 & $-2945,671$ & $-20197,894$ & $-9861,507$ & $-2945,67$ & $-20197,89$ & $-9861,51$ \\
3 & 3460,156 & 11831,241 & 11579,456 & 3460,16 & 11831,24 & 11579,46 \\
4 & $-1492,500$ & $-11831,241$ & $-7359,702$ & $-1492,50$ & $-11831,24$ & $-7359,70$ \\
5 & 3666,138 & 13961,949 & 9441,522 & 3666,14 & 13961,95 & 9441,52 \\
6 & $-1944,933$ & $-13961,949$ & $-5456,519$ & $-1944,93$ & $-13961,95$ & $-5456,52$ \\
7 & 3039,177 & 10958,602 & 7709,029 & 3039,18 & 10958,60 & 7709,03 \\
8 & $-1430,569$ & $-10958,602$ & $-3997,528$ & $-1430,57$ & $-10958,60$ & $-3997,53$ \\
9 & 2401,363 & 8201,057 & 6065,687 & 2401,36 & 8201,06 & 6065,69 \\
10 & $-983,473$ & $-8201,057$ & $-2703,135$ & $-983,47$ & $-8201,06$ & $-2703,14$ \\
11 & 1805,681 & 5744,714 & 4545,392 & 1805,68 & 5744,71 & 4545,39 \\
12 & $-614,135$ & $-5744,714$ & $-1606,858$ & $-614,14$ & $-5744,71$ & $-1606,86$ \\
13 & 1264,400 & 3647,959 & 3179,425 & 1264,40 & 3647,96 & 3179,42 \\
14 & $-334,350$ & $-3647,959$ & $-739,839$ & $-334,35$ & $-3647,96$ & $-739,84$ \\
15 & 789,104 & 1969,311 & 1998,825 & 789,10 & 1969,31 & 1998,82 \\
16 & $-156,161$ & $-1969,311$ & $-133,501$ & $-156,16$ & $-1969,31$ & $-133,50$ \\
17 & 390,785 & 765,420 & 1036,419 & 390,78 & 765,42 & 1036,42 \\
18 & $-117,183$ & $-765,420$ & 179,331 & $-117,18$ & $-765,42$ & 179,33 \\
19 & 65,261 & 146,800 & 284,634 & 65,26 & 146,80 & 284,63 \\
20 & $-82,575$ & $-146,800$ & 110,100 & $-82,58$ & $-146,80$ & 110,10 \\
\hline
\end{tabular}




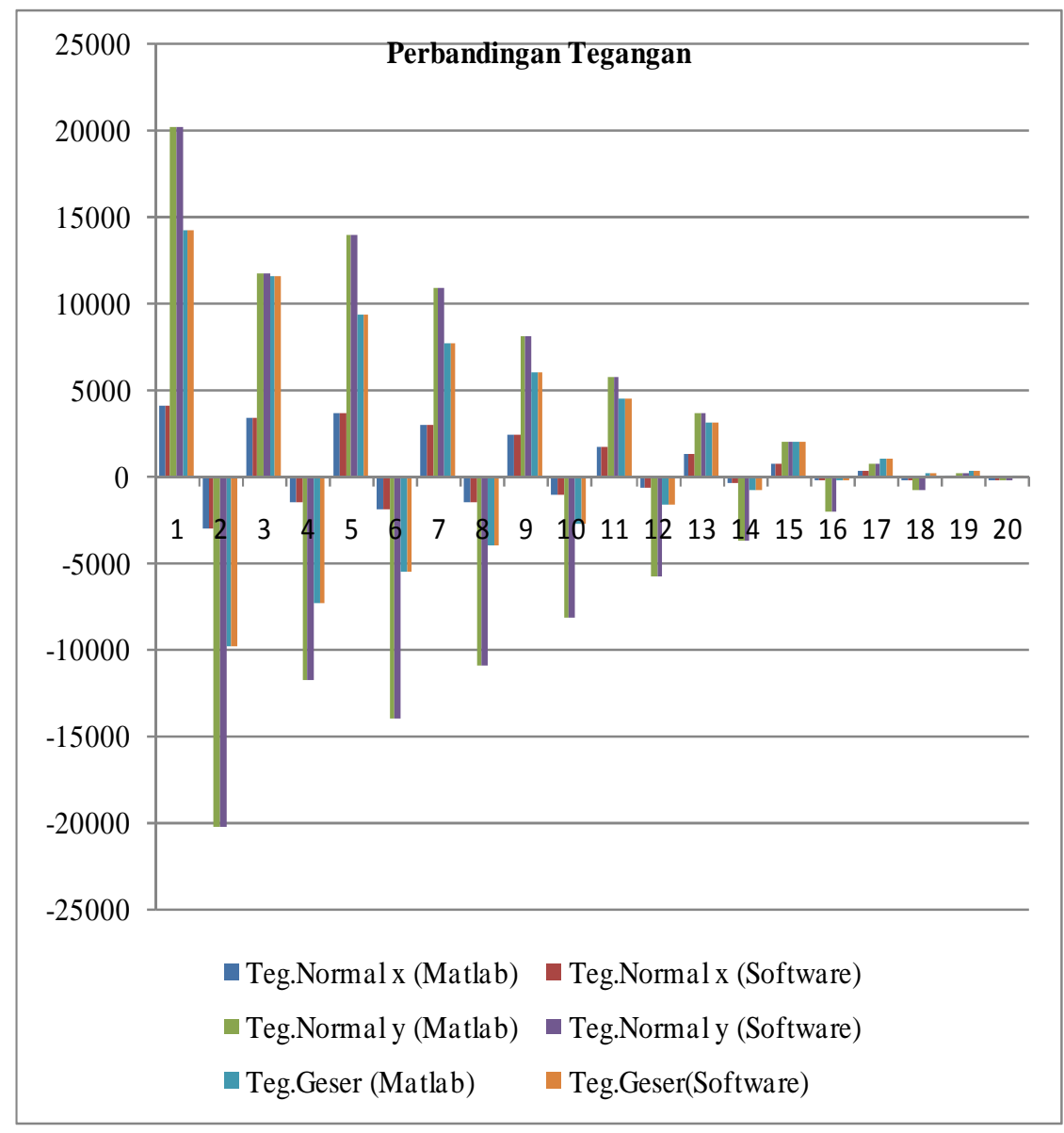

Gambar 16. Perbandingan Grafik Tegangan Bidang

\section{E. KESIMPULAN}

Berdasarkan hasil penelitian, maka dapat disimpulkan beberapa hal sebagai berikut :

1. Dari hasil analisis didapatkan nilai displacement, gaya, regangan dan tegangan pada tiap-tiap elemen bidang dinding geser.

2. Tegangan bidang yang dihasilkan dari analisis ini adalah tegangan normal arah $\mathrm{x}\left(\sigma_{\mathrm{xx}}\right)$, tegangan normal arah y $\left(\sigma_{\mathrm{yy}}\right)$ dan tegangan geser xy $\left(\tau_{\mathrm{xy}}\right)$

3. Perpindahan titik (joint displacement) yang paling dominan terjadi adalah perpindahan titik arah x. Hal ini disebabkan oleh gaya lateral yang bekerja adalah arah x.
4. Perpindahan titik (joint displacement) yang paling besar terjadi pada titik paling atas pada dinding geser, yaitu sebesar $0,26 \mathrm{~m}$ pada titik 21 dan titik 22. Sedangkan pada titik paling bawah atau pada dasar tidak terjadi perpindahan $($ displacement $=0$ ), karena pada dasar dinding geser joint dikekang dengan perletakan sendi.

5. Tegangan maksimum terjadi pada elemen 1, yaitu elemen yang paling bawah dari dinding geser. Besar tegangan pada elemen ini adalah sebesar $\sigma_{\mathrm{xx}}=4039,579 \mathrm{kN} / \mathrm{m}^{2}, \sigma_{\mathrm{yy}}$ $=20197,579 \mathrm{kN} / \mathrm{m}^{2}$ dan $\tau_{\mathrm{xy}}=$ $14208,841 \mathrm{kN} / \mathrm{m}^{2}$. 
6. Perhitungan dengan menggunakan program yang dibuat dengan Matlab sangat baik. Karena hasilnya terbukti sama dengan analisis perhitungan dengan menggunakan Software.

\section{DAFTAR PUSTAKA}

Amrinsyah N., 2010, Metode Elemen Hingga, Institut Teknologi Bandung, Bandung.

Badan Standarisasi Nasional, 2012, Tata Cara Perencanaan
Ketahanan Gempa Untuk

Struktur Bangunan Gedung dan Non Gedung SNI-1726-2012, BSN, Bandung.

Chen W.F., Lui E.M., 2006, Earthquake Engineering for Structural Design, Florida.

Petter K.I., 2008, Matlab Guide to Finite Elements An Interactive Approach, Springer.

Schodek D.L., 1999, Struktur, Edisi Kedua, Erlangga, Jakarta. 